WALDEMAR RAPIOR

\title{
ETNOGRAFIA WIDZIALNOŚCI: ZDJĘCIA JAKO INFORMATORZY
}

\begin{abstract}
Rapior Waldemar, Etnografia widzialności: zdjęcia jako informatorzy [Ethnography of visibility: images as informants] edited by M. Krajewski - „Człowiek i Społeczeństwo”, vol. XXXVI, iss. 2, Poznań 2013, pp. 381-391. Adam Mickiewicz University Press. ISBN 978-83-232-2672-7. ISSN 0239-3271.

Ethnography requires immersion in the field work and the adoption of two perspectives: internal and external. Pure visibility, says Lambert Wiesing, presents things as exclusively visible, released from the laws of physics. You can touch material objects - that entails the possibility of hearing, smelling, and vision. Images could be printed: we feel the smell of ink and a printing machine, texture of media - paper, cardboard or foil. However Wiesing stresses: all we experience in a picture are the qualities detectable by the sense of sight. In this article I present the arguments that the images may be the informants, and ethnography of visibility allows us for awakening the sociological imagination and for analyzing material and visual aspect of the practices. Arguments are based on the interviews conducted with the "Invisible city" project team as well as on the analysis of images from the database: www.niewidzialnemiasto.pl.
\end{abstract}

Waldemar Rapior, Uniwersytet im. Adama Mickiewicza w Poznaniu, Instytut Socjologii, ul. Szamarzewskiego 89c, 60-569 Poznań, Poland.

Znak, według klasycznej definicji - aliquid, quo stat pro aliquo - odsyła do czegoś, co nim nie jest. Fotografia traktowana jako znak odsyła do: (a) tego, co na obrazie - odniesienie przedmiotowe, (b) sposobu patrzenia - odniesienie do sposobu widzenia świata, (c) znaczenia - odniesienie symboliczne, (d) innych obrazów - odniesienie narracyjne. Fotografię możemy zatem odczytać: zdjęcie Walkera Evansa bliźniaczo do siebie podobnych domów i bilbordów w Atlancie - przypadek (a); zdjęcie okularów z jednym szkłem obrazujące, jak postrzega krótkowidz - przypadek (b); zdjęcie Margaret Bourke-White stojących w kolejce po żywność czarnoskórych kobiet i mężczyzn na tle bilbordu wieszczącego american way of life - roześmianej białej rodziny $\mathrm{w}$ nowym aucie, to przypadek (c); historie opowiedziane przez Rona Haviva za pomocą następujących po sobie zdjęć - przypadek (d). 
Zdjęcia są znakami, gdyż ktoś używa ich jako obiektów, za pomocą których odnosi się do czegoś. Właściwością zdjęć nie jest bycie znakiem. Stają się nim przez sposób użycia. Właściwością zdjęć, tak jak i innych obra-

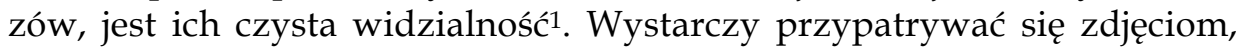
nie trzeba ich czytać. Aby zdjęcie mogło być użyte jako znak, najpierw musi coś pokazać.

Czysta widzialność obrazu, jak uważa Lambert Wiesing, jest widzialnością oczyszczoną z przyczynowych stosunków pomiędzy rzeczami, z fizycznego ciążenia świata. Właściwością obiektów materialnych jest to, że można ich dotknąć, co pociąga za sobą możliwość słyszenia, wąchania, widzenia. Zdjęcie można wydrukować: czujemy zapach farby i maszyny nadrukowującej, fakturę nośnika - papieru, kartonu, folii. Wiesing jednak wskazuje: obraz jest tym, co jest wyłącznie widzialne. Obiekt materialny można dotknąć, na obiekty materialne na obrazach należy patrzeć.

Etnografowie przyjmują perspektywę zewnętrzną, tj. obserwują, oraz wewnętrzną, tj. uczestniczą w społeczności, którą badają. Patrzą i dotykają. Jeśli na zdjęcia możemy tylko patrzeć, czy możliwa jest etnografia zdjecć? Eiko Ikegami przeprowadziła badania w środowisku gry Second Life ${ }^{2}$. Pokazała, że relacje oraz interakcje między awatarami są relacjami łączącymi ludzi w taki sam sposób jak w innych enklawach codzienności, w których interakcje są celem samym $\mathrm{w}$ sobie - restauracji, parku rozrywki, przestrzeni zabaw i gier. Spotkanie twarzą w twarz z badanym nie jest konieczne Ikegami odnotowała złożone interakcje między awatarami. Na czas badania przybrała postać awatara, wyruszając do innego świata, jak to czynili kiedyś antropologowie.

W przypadku „niewidzialnego miasta” mamy dostęp do bazy zdjęć. Te zaś nie zmieniają się, gdy na nie patrzymy. Michael Angrosino przedstawia, czym jest etnografia: to opis grup ludzkich, ich codziennego życia. Metoda etnograficzna różni się od innych sposobów prowadzenia badań, gdyż: (a) opiera się na pracy w terenie (prowadzi się je w środowisku badanego), (b) jest spersonalizowana (badacz wchodzi $\mathrm{w}$ bezpośredni kontakt $\mathrm{z}$ badanymi) i (c) wieloczynnikowa (korzysta się z kilku technik zbierania danych), (d) wymaga długotrwałego zaangażowania, (e) opiera się na indukcji (akumulacja szczegółów prowadzi do wskazania ogólnego wzoru lub stworzenia teorii) i (f) dialogu (badani komentują wnioski z badań na bieżąco), (g) ma charakter holistyczny (opis ma ukazać jak najpełniejszy obraz badanej społeczności) ${ }^{3}$.

\footnotetext{
${ }^{1}$ L. Wiesing, Widzialność obrazu. Historia i perspektywa estetyki formalnej, Warszawa 2008.

2 E. Ikegami, Visualizing the Networked Self: Agency, Reflexivity, and the Social Life of Avatars, „Social Research” 2011, vol. 78, no. 4.

${ }^{3}$ M. Angrosino, Badania etnograficzne i obserwacyjne, Warszawa 2010, s. 44-46.
} 
Pojęcie „niewidzialne miasto” bezpośrednio odwołuje się do widzialności jako właściwości obrazu. Sugeruje, że pewna kultura miejska jest niedostrzegana, ale również, że obrazy mają zdolność uczynienia czegoś widzialnym. Wypowiedź jednego z realizatorów projektu "Niewidzialne miasto" $(\mathrm{NM})$ : „moim zdaniem [,niewidzialne miasto"] istniało, ale $\mathrm{w}$ formie rozproszonych działań, w których nie dostrzegaliśmy całości, nadanie nazwy pozwoliło te podobieństwa dostrzec" $(145)^{4}$. Pojęcie zostało wypełnione treścią w postaci zdjęć. To, co istniało, zostało sfotografowane. Wyruszaliśmy $\mathrm{w}$ teren, aby zdobyć materiał. Byliśmy etnografami. Interesuje mnie etap kolejny, czyli wybór i analiza wyselekcjonowanych zdjęćs. Stawia on przede mną pytanie: czy terenem dla etnografa może być obraz?

„Wizualny skręt” (165) kategorii „niewidzialnego miasta” (nm) był często podkreślany $\mathrm{w}$ ankietach autoewaluacyjnych. Zdjęcia $\mathrm{w}$ bazie NM przedstawiają zbiór "oddolnie realizowanych inicjatyw mieszkańców" (161). $\mathrm{NM}$ „pozwala dostrzec całe mrowie miejskich [...] czynności, pozwala spojrzeć na miasto jako na ciągłą, gęstą, pulsującą strukturę" (165). Ta gęsta struktura jest zawarta w obiektach materialnych uchwyconych na zdjęciach, które jednak pozwalają „obserwować jedynie to, co widzialne - innymi słowy, nie pozwala odpowiedzieć na pytanie - dlaczego niektórzy ludzie nie pozostawiają żadnych śladów" (160). Wyniki autoewaluacji mówią: projekt nie dokumentuje „hiperulotnych” przejawów nm oraz działań (180), usytuowania przestrzennego i czasowego poszczególnych realizacji względem siebie ani „zmienności” i „przemijalności” realizacji nm (137). Zdjęcia pozwalają jedynie obserwować "materialne rezultaty" (180). Idąc dalej, czysta widzialność i dokumentacja materialnych rezultatów działalności mieszkańców powoduje, że „zaczęliśmy je [nm] oglądać z jednej tylko perspektywy - jako oddolne interwencje $\mathrm{w}$ przestrzeń miejską dokonywane przez mieszkańców, a nie na przykład dewastacje, rujnowanie ładu estetycznego, upowszechnianie małomiasteczkowego gustu" (153). Nasze rozmowy o nm,

4 Projekt „Niewidzialne miasto” (NM) narodził się w 2007 roku w Zakładzie Badań Kultury Wizualnej i Materialnej w Instytucie Socjologii UAM w Poznaniu. Polegał na dokumentacji fotograficznej oddolnych, spontanicznych interwencji mieszkańców w przestrzeń miejską. W latach 2009-2012 prowadziliśmy badania w ramach grantu MNiSW NN116433837. Głównymi elementami grantu była analiza zdjęć znajdujących się $\mathrm{w}$ bazie NM, wywiadów z twórcami interwencji miejskich oraz z ekspertami odpowiedzialnymi za przestrzeń miasta. Jednym z komponentów badania była także autoewaluacja badaczy - każdy z nas odpowiedział na serię pytań otwartych ankiety autoewaluacyjnej. Numery w nawiasach, np. (145), są kodami przypisanymi każdej ankiecie w celu zwiększenia anonimowości zawartych $\mathrm{w}$ nich wypowiedzi. Wszystkie szczegóły metodologiczne znajdują się w Internecie, zob. http://nmbadania.info[dostęp: 2.02.2014] oraz http://www.niewidzialnemiasto.pl [dostęp: 2.02.2014].

${ }^{5} \mathrm{~W}$ bazie znajduje się ponad 6000 zdjęć; nasza analiza objęła około $400 \mathrm{z}$ nich. 
pierwsze zdjęcia i dyskusja o nich, ustaliły treść (materialne rezultaty interwencji mieszkańców w przestrzeń miejską) oraz formę (nie estetyzujemy, nie kombinujemy, zdjęcia mają być "dziurkami od klucza”). Na poziomie fotografowania wkradała się „rutyna” (159) - „pomimo wielu fotografów, ich spojrzenie - takie mam wrażenie - jest w dalszym ciągu podobne" (174). Jak można uprawiać etnografię zdjęć, skoro pojawia się tu tak wiele wątpliwości, zbyt duża redukcja "gęstych struktur"?

Zdjęcia zamieszczone w bazie NM „należy «czytać» obowiązkowo w powiązaniu z raportami z badań, wywiadami, filmami etc." (159). Zdjęcia umieszczone $\mathrm{w}$ kontekście pozostałych materiałów badawczych stają się częścią, opowiedzianej z wielu punktów widzenia, narracji o mieście. Obrazy przekształcone są w znaki, które trzeba przeczytać. „Główną zaletą przyjętego podziału, sposobu organizacji bazy zdjęciowej, jest uczytelnienie sposobów «czytania miasta» przez realizatorów projektu" (137). Czytając, waloryzujemy interwencje zamieszczone w bazie NM. Dzięki refleksji nad sposobem czytania wiemy, jakie znaczenia nadajemy poszczególnym realizacjom: „ograniczony jest zazwyczaj sposób, w jaki myślimy o modyfikacjach dokonywanych $w$ mieście, ograniczając je do kategorii estetycznych (upiększanie) lub instrumentalizując (produktywność), nie dostrzegając ich więziotwórczego potencjału" (174). Patrzenie jest jednak czymś innym niż czytanie. Etnograf nie tylko odczytuje, lecz także obserwuje: inskrypcje, teksty, znaki. Patrzymy i rozpoznajemy - i to wystarczy. Pojawia się realna obawa: „istnieje bowiem zagrożenie, że się go [projekt NM] sprowadzi do wizualności”, i dalej: „cała wizualna metaforyka sprzyja myśleniu strukturalnemu [...], które - paradoksalnie - wyklucza fenomen, który badamy, i który jesteśmy w stanie dostrzec tylko w kategoriach relacyjnych"6 (174). I jeszcze: "gdy myślimy strukturalnie, powiemy, że «niewidzialne miasto» jest ładne/brzydkie/ambiwalentne w swej urodzie, o powszechnej bądź zróżnicowanej estetyce, symboliczne, zapominając jednocześnie, że jest ono (być może bardziej niż miasto widzialne, co byłoby jedną z jego specyfik) performatywne, cielesne, mięsne, emocjonalne, nawykowe, materialne, taktyczne" (174). Pojawiają się tutaj te same problemy: oczyszczenie obrazu z innych właściwości (kinetycznych, audialnych, haptycznych) raczej zakrywa, niż pokazuje. Zwłaszcza to, co jest najważniejsze dla autora powyższego cytatu: więziotwórczy potencjał, który można dostrzec tylko w kategoriach relacyjnych. "Niewidzialne miasto" staje się ponownie niewidzialne. Pomimo tych wszystkich trudności i ograniczeń, właśnie w widzialności zdjęć widzę ukrytą potencję - możliwość patrzenia.

\footnotetext{
${ }^{6}$ To samo w kontekście bazy NM: „Kiedy teraz myślę o bazie, to przychodzą mi do głowy problemy, o których mówiłem wyżej, a więc zagrożenia sprowadzenia «niewidzialnego miasta» do obrazu właśnie, co nie sprzyja jego zrozumieniu i dowartościowaniu" (174).
} 
Wybór zdjęć do analizy zwykle przebiegał w podobny sposób. Najpierw przeglądanie wszystkich zdjęć znajdujących się w badanej kategorii: Zwierzyniec, Miejsca dziecięce, Upiększenia itd. Następnie określenie celu: „Zaczynałem od wyodrębnienia typów" (174). W trakcie pracy większość z nas robiła notatki i fiszki. Oto dwa opisy próbowania się z obrazami:

(170): „,...przeglądając je [kategorie] - pewnie kilkanaście razy tam i z powrotem i robiąc przy tym notatki na zasadzie luźnych skojarzeń i spostrzeżeń. Następnie notatki starałem się układać w pewną logiczną całość, wyodrębniając w ten sposób najczęściej powtarzające się motywy. Takie zarządzanie notatkami pozwoliło następnie na wybór tych zdjęć, które poddawane były szczegółowej analizie".

(159): „Do przeglądanych kilkukrotnie zdjęć dopisywałam każdorazowo (i do każdego zdjęcia!) refleksje, impresje, oraz ich opisy w stylu: na pół zardzewiała konstrukcja stojąca najprawdopodobniej na blokowisku etc. Z opisów powstały robocze typy idealne realizacji".

Powyższe fragmenty opisują nie sposoby czytania zdjęć, ale ich oglądania. W przypadku wywiadów możemy dokonać transkrypcji zapisu. Tekst możemy następnie przeczytać. Jednak nie trzeba tego robić. Jean-Claude Kaufmann odsłuchuje materiał zapisany na taśmie i spisuje tylko te fragmenty, które są obrazowe, wyraziste, nasycone informacjami, intrygujące, zbliżone do opracowywanych właśnie hipotez. Nagrana rozmowa jest bogatsza, bardziej złożona: „rytm, intonacja i chwile ciszy są komentarzami do tekstu"7. Bogactwo jest ukryte zarówno w treści wypowiedzi, jak i w samym głosie, w dźwięku. Fotografia pokazuje: „szczególnie ważny był ich kontekst - tzn. w jakim miejscu znajduje się dana realizacja (huśtawka w prywatnym ogrodzie vs huśtawka na blokowiskowym placu zabaw)" (159). Co pokazują zdjęcia w bazie NM? Odpowiedź brzmi: materialność.

Posłużę się tutaj moim przypadkiem - kategorią Zwierzyniec. Wyżej przywołana wypowiedź o huśtawkach wyraża to samo, co chcę w tym akapicie powiedzieć. Przeglądając zdjęcia, zwracałem uwagę na aspekt materialny interwencji znajdujących się na nich. Być może taka była specyfika projektu i fotografii o takiej treści i takiej formie. Najpierw karmniki: te o pochyłych dachach; jednopoziomowe, wielopoziomowe; wykonane $\mathrm{z}$ butelek po wodzie mineralnej; zawieszone na drzewach, postawione na parapetach i balkonach. Potem domy dla kotów: zrobione z mebli, z kartonów; tzw. kocury, czyli uchylone piwniczne okna. Wreszcie budy psów: za ogrodzeniem, duże, małe. Zwracałem uwagę na kolor, skalę, podobieństwo, kontekst, w którym się znajdują, estetykę. W taki sposób powstały typy, które nasycałem kolejnymi zdjęciami. Jakimi? Odpowiedzią niech będzie

${ }^{7}$ J.-C. Kaufmann, Wywiad rozumiejacy, Warszawa 2010, s. 122. 
fragment autoewaluacji: „możliwość odszyfrowania na zdjęciu jak największej ilości skojarzeń i asocjacji związanych z danym typem idealnym danego aspektu «niewidzialnego miasta»" (159).

Rozpowszechnienie obrazów fotograficznych w XIX wieku uświadomiło ludziom, jak bardzo ich życie zależy od zarządzania obiektami materialnymi. Pokazując ubrania, rzeczy osobiste, ciała i twarze ludzi, fotografia wskazywała, na ile panujemy nad środowiskiem materialnym. Zdjęcia, unieruchamiając obiekty i sytuacje, uśmiercają je, a jednocześnie ożywiają tych, którzy na nie patrząi ${ }^{8}$ Prosty i tani sposób produkcji obrazów, nie tylko fotograficznych, pozwolił powiedzieć Jeanowi Baudrillardowi, że współczesną formą ikonoklazmu jest nadprodukcja obrazów. Dlatego tak ważne są dziś wszelkiego rodzaje sposoby wizualizacji danych i informacji. Typografia, grafika użytkowa, komunikacja wizualna - wszystkie te dziedziny kreują sposób prezentacji książek, zdjęć, mebli, zabawek, etykietek na lekarstwach. W tych działaniach nie chodzi jednak o czystą widzialność, lecz o wyodrębnienie $\mathrm{z}$ tła, o przyciąganie uwagi.

W.J.T. Mitchell pyta, czego chcą od nas obrazy? I odpowiada: obrazy chcą, abyśmy pytali je, czego od nas chcą ${ }^{9}$. Roland Barthes wskazuje natomiast na studium, czyli warstwę informacyjną obrazu, oraz punctum, czyli coś, co nas chwyta, przeszywa ${ }^{10}$. Obrazy pobudzają naszą wyobraźnię, absorbują, pokazują. Etnograf może skorzystać ze zdjęć w celach dokumentacyjnych. Wówczas studium będzie dla niego najważniejsze: zdjęcia pokazują sposób ubierania albo noszone fryzury w danym miejscu i czasie. Jednak zdjęcia chcą, abyśmy na nie patrzyli dla samej widzialności tego, co się znajduje na powierzchni nośnika. Punctum przeszywa ciało patrzącego. Nie jest zależne od naszej woli. Dzieje się tak, ponieważ wizerunki patrzą na nas psują nam samopoczucie (dowody zdrady albo obrazy głodujących dzieci), wprawiają nas w osłupienie (sztuczki, fuszerki), szokują, obrażają, wyzwalają radość, budzą wspomnienia (zdjęcia rodzinne), nie powalają zamknąć oczu lub do tego zmuszają (widok cierpienia). Spojrzenie obrazów jest spojrzeniem społecznym - obrazy kształtują nasze zachowanie.

Jeśli przyjmiemy, że obrazy mają zdolność do działania i pobudzania do działania, musimy uznać, że są one podobne do nas, ludzi. Obrazy nie są tylko przedmiotem, ale również podmiotem. Przedmiot zwykle jest utożsamiany z biernością, jest obiektem, którym się manipuluje i którego się używa. Podmiot jest zdolny do używania, manipulowania, jest aktywny -

${ }^{8}$ R. Drozdowski, M. Krajewski, Za fotografię! W stronę radykalnego programu socjologii wizualnej, Warszawa 2010.

${ }^{9}$ W.J.T. Mitchell, What Do Pictures Want?: The Lives and Loves of Images, Chicago 2005.

${ }^{10}$ R. Barthes, Światto obrazu, Warszawa 1996. 
działa11. Tę antropocentryczną perspektywę - tylko ludzie są podmiotami należy złagodzić. Obrazy są elementem złożonej sytuacji, w której ludzie, zwierzęta, obiekty materialne i obrazy wchodzą ze sobą w relacje. Proponuję, aby potraktować zdjęcia znajdujące się w bazie NM jako informatorów. W etnografii informator to osoba, która żyje w danej kulturze lub ma wiedzę zazwyczaj nie teoretyczną, ale pochodząca ze społeczności badanej - na temat badanego terenu. Wobec informatorów etnograf powinien zachować takt i skromność. Oni są najistotniejsi. Na czas trwania interakcji badaczinformator ten pierwszy powinien się zaangażować w sytuację badawczą. Powinien stać się kimś bliskim: uśmiechać się, nawet głośno śmiać, zdradzać swoje opinie, bezpośrednio analizować to, co przed chwila powiedział informator ${ }^{12}$. W przypadku zdjęć cała interakcja zawężona jest do patrzenia.

Jak podkreśla Angrosino, „,z metod etnograficznych warto korzystać, jeżeli ważnym celem studiów jest dotarcie do perspektywy, z jakiej badane kwestie postrzega dana społeczność"13. Zdjęcia można postrzegać jako wyraz perspektywy - sposobu patrzenia osoby fotografującej. Pytamy wówczas o intencję fotografa, o reżimy kulturowe, w których on uczestniczy, o konwencję fotografowania, o technologiczne kształtowanie sposobu robienia zdjęć. Zajmuje mnie tutaj nie to, co dzieje się za obiektywem aparatu fotograficznego, ale to, co dzieje się przed nim - to, co utrwalone na zdjęciu. Jak już pisałem, fotografujący, pomimo że początkowo musieli zdefiniować, czym jest "niewidzialne miasto", robili zdjęcia rutynowo. Rutynowo nie znaczy tu: automatycznie, lecz: po zdefiniowaniu, jakie obiekty tworzą „niewidzialne miasto", a ich wizerunki zapadają w pamięć. To ułatwiało wybór interwencji z otoczenia miejskiego. Nauczyliśmy się formy i treści. Dlatego większość zdjęć jest do siebie podobnych. „Nie interesowała mnie w ogóle jakość zdjęcia" (174) - to powszechne podejście osób analizujących zdjęcia.

Zdjęcie-informator przechowuje zmemoryzowane, w postaci obiektów materialnych, kody zachowań społecznych. Interwencje w przestrzeń miejską dokonywane przez mieszkańców są wyrazem (a) wzoru kulturowego, np. architektura karmników dla ptaków jest oparta na tradycyjnej architekturze wiejskiej (sielanka, przyroda, wieś jako naturalny łącznik ludzi i zwierząt), ale też (b) radzenia sobie $\mathrm{z}$ materialnością, np. ponowne wykorzystanie plastikowych butli po wodzie mineralnej w roli karmników. Zachowania społeczne są nakierowane na innych ludzi (np. znaki nakazujące posprzątanie po swoim psie), zwierzęta (np. plastikowe butelki wetknięte we wnękę nad balkonem, aby uniemożliwić przesiadywanie tam ptakom), przed-

\footnotetext{
${ }^{11}$ R. Drozdowski, M. Krajewski, op. cit.

12 J.-C. Kaufmann, op. cit., s. 81.

${ }^{13}$ M. Angrosino, op. cit., s. 52.
} 
mioty materialne (np. wykorzystywanie pudełek po margarynie jako misek na pokarm dla zwierząt). Zdjęcia są znakami, gdyż umożliwiają przeniesienie i zgromadzenie tysięcy interwencji $\mathrm{w}$ przestrzeń miejską $\mathrm{w}$ jednym miejscu (baza NM). Są przede wszystkim obrazami, ponieważ pokazują, czynią coś widzialnym.

Zdjęcia w bazie NM zachowują, tak jak odcisk ludzkiej stopy, czyjąś obecność, lecz również zachowania społeczne. William Golding opowiada o śladach pozostawionych $w$ jaskini w Owerni ${ }^{14}$. Obok śladu stopy znajduje się wgłębienie - ślad kija. Dzięki zdolności utożsamienia się z ruchami ciała, zwanej współczulną kinestezją, możemy sobie wyobrazić, że osoba przechodząca przez zbiornik wodny, który kiedyś był błotem, zachwiała się i podparła kijem. Z licznych innych śladów możemy wywnioskować, iż była to kobieta. Zdjęcia pobudzają nie tylko zmysł wzroku, lecz także naszą pamięć, uczucia, zmysł kinetyczny, smak, powonienie ${ }^{15}$. Prowadząc wywiad $\mathrm{w}$ terenie $\mathrm{z}$ informatorem, staramy się być jego przyjacielem - cierpliwie, życzliwie i z ciekawością wysłuchiwać, co ma do powiedzenia. Współczulna kinestezja byłaby postulatem, jak ma przebiegać interakcja $\mathrm{z}$ fotografią. Zdjęcia pozwalają na, jak powiedziałby Kaufmann, pełen wrażliwości kontakt z historią życia. Pokazują, jak przebiega życie, pokazują kontekst i sposoby radzenia sobie ze światem materialnym.

Gdy już wybraliśmy zdjęcia do analizy, należało stworzyć ich profile. Profil zdjęcia wytwarzaliśmy, opierając się na narzędziu analizy, dzięki czemu fotografie przeglądane były przez „wykalibrowane przez instrukcje spojrzenie aktora ludzkiego" (153). Narzędzie składało się z wymiarów (czas, przestrzeń, funkcja, relacje społeczne, materialność, wykonanie, estetyka). Każdy wymiar doprecyzowany został kilkoma opozycjami, np. czas: tymczasowe-trwałe, codzienne-odświętne, doczesność-unieśmiertelnienie, jednorazowe-cykliczne itd.

Proces wyboru zdjęć i tworzenia typów, nawet jeśli był „bardzo trudny, generował wiele dyskusji i kontrowersji" (156), a być może właśnie dlatego, przebiegał w sposób intuicyjny. Był to proces szukania i uwrażliwienia się na to, co na zdjęciach: „nie kierowałem się kryteriami losowymi, lecz przeglądałem wszystkie zdjęcia w kategorii [...], poszukując tych, w których najbardziej uderzy mnie «instant»" (137). Narzędzie do analizy natomiast to "gorset, który uwiera, ale jest niezbędny, żeby umożliwić intersubiektywną sprawdzalność i intersubiektywną komunikowalność" (193). Zdjęcia trzeba było zamknąć w opozycjach. Język werbalny i tekstowy, przy całej swej wieloznaczności, jest jednoznaczny. Gramatyka języka redukuje jego nie-

14 W. Golding, Ruchomy cel, Poznań 1997.

15 S. Pink, A Multisensory Approach to Visual Methods, [w:] Visual Research Methods, eds E. Margolis, L. Pauwels, Los Angeles-London-New Delhi-Singapore-Washington 2011. 
jednoznaczność. Do tego, co widzialne, musimy stworzyć gramatykę. Stąd pewnie "niezwykle trudno było o powstrzymanie się od arbitralności” (160).

Narzędzie analizy pełniło rolę podwójną: kalibrowało spojrzenie badacza i nakładało na zdjęcie gorset. Ten podwójny ruch był widoczny niemal w każdej ankiecie autoewaluacyjnej. $Z$ jednej strony trudności z dopasowaniem opozycji do tego, co na zdjęciu, $\mathrm{z}$ drugiej kłopoty $\mathrm{z}$ definiowaniem opozycji poprzez to, co przedstawia zdjęcie. „Budowanie tzw. «wymuszonych połączeń» pozwalało dostrzec w realizacjach wymiary, które inaczej nie przyszłyby lub trudniej przychodziłyby do głowy" (174). Mnogość zdjęć w bazie w obrębie poszczególnych kategorii wymuszała połączenia: opozycje były weryfikowane przez zestawienie ze sobą obrazów, gdyż interwencje miejskie $\mathrm{w}$ obrębie jednej kategorii (np. Zwierzyniec) potwierdzały intuicję i użycie opozycji przez badacza lub przeciwnie - falsyfikowały je. Podobnie było wtedy, gdy zaczęliśmy porównywać różne kategorie do siebie: „co znaczy piękne w Protezach instytucji, kiedy ten wymiar pewnie mało się dla twórców liczy, a nie wynika to z niedbalstwa, albo cóż oznacza nielegalność w przypadku Protez, kiedy nm wytwarza w zasadzie własną kategorię rozumienia legalności" (174). Zmaganie się z obrazem, z jednej strony, było próbą znalezienia gruntu, uniknięcia wieloznaczności, z drugiej - to właśnie obrazy precyzowały opozycje.

Podwójności wieloznaczność-precyzja nie należy traktować w kategoriach zysk-strata. Raczej wieloznaczność była redukowana, a precyzja wzrastała w miarę pracy nad spojrzeniem i materialnością, którą uwidaczniał obraz. Krótko mówiąc, chodzi o dążenie do opanowania tematu. Wcześniej przywołałem fragmenty wypowiedzi dotyczącej tego, że baza zdjęć nadmiernie akcentuje wizualność, że wiele zakrywa przez strukturalne podejście widzialne-niewidzialne. Jednak $\mathrm{w}$ miarę jak realizatorzy projektu wgłębiali się w widzialność - wybierając kategorie, porównując zdjęcia, dopasowując opozycje - pojawiały się nowe pomysły i spojrzenia. Obrazy zaczęły pokazywać też relacje.

Weźmy następujące pytanie z ankiety autoewaluacyjnej: „Czy po zakodowaniu realizacji zmieniało się Twoje spojrzenie na niewidzialne miasto?". Pojawiło się kilka odpowiedzi, że nie, ale większość to odpowiedzi twierdzące, odpowiedzi na tak: „moje spojrzenie z pewnością było bardziej holistyczne, obiektywne, takie z lotu ptaka” (193) albo: „moje spojrzenie uległo zmianie, ale raczej moja opinia dążyła $\mathrm{w}$ odwrotnym kierunku - zamiast powtarzalności, którą wcześniej zauważałem, zacząłem dostrzegać dużą różnorodność $\mathrm{w}$ detalach [...] szczegółowa analiza raczej oddalała mnie od spójnej syntezy” (160). Pojawiły się nowe pomysły interpretacyjne: „dzięki owemu zróżnicowaniu kryteriów [wymiary i opozycje] powstał pomysł 
potraktowania nm jako kulis miasta” (170). Dalej: „analiza - vide raport wygenerowała cały szereg nowych spojrzeń i tez: prywatyzacja miasta, ciche sojusze, kultura oboczna, brak zgodności tego, co ładne i dobre" (153). Kodowanie umożliwiło przejście z logiki „«albo - albo» w logikę «i - i». Gdyby nie te siłowe, nachalne opozycje, być może nie doszlibyśmy do tego wniosku tak szybko" (181). Praca i opanowywanie materiału jest też ćwiczeniem z współczulnej kinestezji. Widzimy i analizujemy, więc poznajemy i objaśniamy.

Etnografia widzialności, odmiennie niż tradycyjna etnografia, nie opiera się na dwóch zasadach - bycia jednocześnie obserwatorem i uczestnikiem. Ten pierwszy komponent roli etnografa pozwala zdystansować się od tego, co się dzieje w danej społeczności, drugi - być jego integralnym elementem, co ułatwia poznanie od środka. W przypadku etnografii widzialności nie ma mowy o uczestnictwie. Obserwacja-uczestnictwo jest sposobem funkcjonowania w społeczności. Ani jedno, ani drugie nie pozwalałoby na odtworzenie wzorów kulturowych, gdyby nie zaangażowanie, które wyklucza neutralność i zbyt duży dystans. Badacz, patrząc, wybierając obrazy i analizując je, może zaangażować się w świat, który one pokazują, zacząć szukać powiązań między różnymi interwencjami, próbować odpowiedzieć na pytanie, co użytkownicy tych obiektów robią z owymi przedmiotami i dlaczego.

Etnografia widzialności nie jest analizą - analiza danych jest etapem w ramach etnografii. Chodzi o postawę zaangażowaną w zdjęcia. Oznacza ona: (a) uznanie, że zdjęcia nie są tylko interpretacją rzeczywistości, ale też (b) opis: „filtrowanie to nie fabrykowanie" 16 - wybór fragmentów z rzeczywistości nie jest wytwarzaniem zjawisk, (c) wyjście poza opozycję realizmfikcja i zwrócenie uwagi na przeplatającą się aspektowość rzeczywistości, (d) fakt, że obrazy pozwalają zanurzyć się w tym, co przedstawiają, podobnie jak czytana powieść. W przypadku tej ostatniej czytelnik może dość swobodnie wyobrazić sobie historię. Zdjęcia natomiast przekazują „komunikat zwrotny" w postaci wizerunków i materialności. I jeszcze to, że (e) zdjęcia mają swojego autora, podobnie jak wywiad, który jest przez kogoś przeprowadzany. Fotografie są informatorami. W widzialności zapisana jest wiedza, podobnie jak w głowach i ciałach ludzkich informatorów. Badacz musi włożyć wiele wysiłku, aby tę wiedzę wydobyć i zanalizować. Angażując się w patrzenie na zdjęcia, angażujemy naszą pamięć, pobudzamy też zmysły - wchodzimy do materialnego świata, który leży przed naszymi oczami, po to, by zrozumieć ludzi, ich relacje z otoczeniem, życie przedmiotów albo zwierząt w jednej sytuacji, społecznie i fizycznie określonej.

16 J. Lofland, D.A. Snow, L. Anderson, L.H. Lofland, Analiza układów społecznych. Przewodnik metodologiczny po badaniach jakościowych, Warszawa 2009, s. 126. 
W początkowych partiach tego tekstu wskazywałem na ograniczenia związane $\mathrm{z}$ patrzeniem na zdjęcia zamieszczone $\mathrm{w}$ bazie NM. Pisałem też o pomysłach interpretacyjnych wypływających z analizy tego, co widzialne. Gdyby nie zaangażowanie realizatorów projektu, byłyby one ukryte, tak jak ukryte są sposoby życia ludzi w jakieś społeczności przed etnologiem.

\section{BIBLIOGRAFIA}

Angrosino M., Badania etnograficzne i obserwacyjne, Warszawa 2010.

Barthes R., Światto obrazu, Warszawa 1996.

Drozdowski R., Krajewski M., Za fotografię! W strone radykalnego programu socjologii wizualnej, Warszawa 2010.

Golding W., Ruchomy cel, Poznań 1997.

Ikegami E., Visualizing the Networked Self: Agency, Reflexivity, and the Social Life of Avatars, „Social Research" 2011, vol. 78, no. 4.

Kaufmann J.-C., Wywiad rozumiejący, Warszawa 2010.

Lofland J., Snow D.A., Anderson L., Lofland L.H., Analiza układów społecznych. Przewodnik metodologiczny po badaniach jakościowych, Warszawa 2009.

Mitchell W.J.T., What Do Pictures Want?: The Lives and Loves of Images, Chicago 2005.

Pink S., A Multisensory Approach to Visual Methods, [w:] Visual Research Methods, eds E. Margolis, L. Pauwels, Los Angeles-London-New Delhi-Singapore-Washington 2011. Wiesing L., Widzialność obrazu. Historia i perspektywa estetyki formalnej, Warszawa 2008. 